Jurnal Health Sains: p-ISSN : 2723-4339 e-ISSN : 2548-1398

Vol. 2, No. 2, Februari 2021

\title{
GAMBARAN GANGGUAN RESPIRASI DI KABUPATEN ACEH TENGGARA TAHUN 2015-2019
}

Suci Ramadani Mr

Universitas Abulyatama Aceh, Aceh Besar, Indonesia

Email: rsuci9161@gmail.com

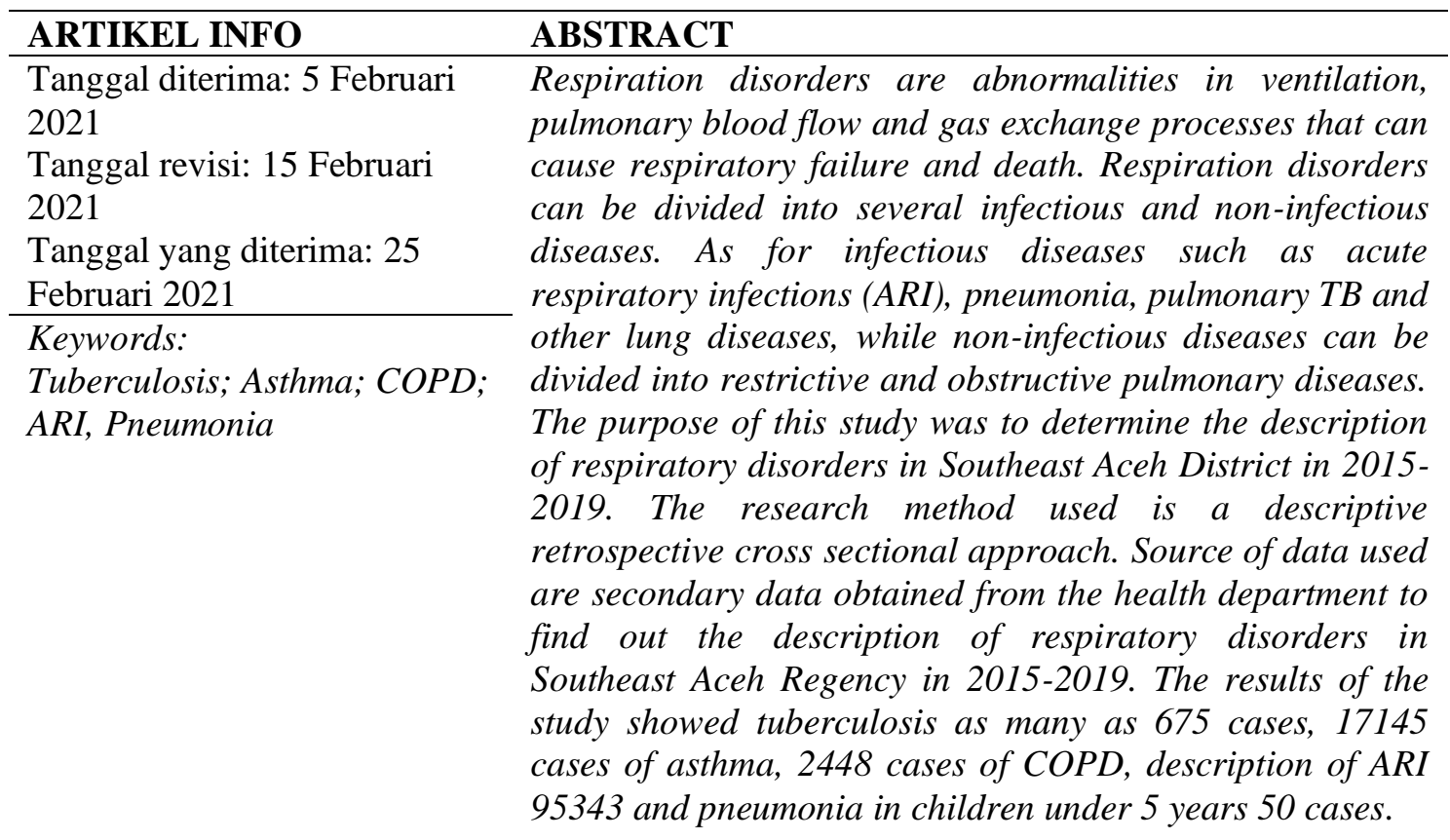

Kata Kunci:

Tuberkulosis; Asma; PPOK; ISPA; Pneumonia

\begin{abstract}
ABSTRAK
Gangguan respirasi adalah dijumpai kelainan ventilasi, aliran darah paru dan proses pertukaran gas yang dapat menyebabkan gagal napas dan kematian. Gangguan respirasi dapat dibagi menjadi beberapa penyakit infeksi maupun non-infeksi. Adapun penyakit infeksi misalnya Infeksi Saluran Pernafasan Akut (ISPA), pneumonia, TB Paru dan penyakit paru lainya, sedangkan penyakit noninfeksi dapat dibagi menjadi penyakit paru restriktif dan obstruktif. Tujuan Penelitian ini adalah untuk mengetahui gambaran gangguan respirasi di Kabupaten Aceh Tenggara tahun 2015-2019. Metode penelitian yang dipakai adalah deskriftif restrospektif dengan pendekatan cross sectional. Sumber data yang digunakan adalah data sekunder yang diperoleh dari dinas kesehatan untuk mengetahui gambaran gangguan respirasi di Kabupaten Aceh Tenggara Tahun 2015-2019. Hasil penelitian gambaran tuberkulosis sebanyak 675 kasus, gambaran asma 17145 kasus, gambaran PPOK 2448 kasus, gambaran ISPA 95343 dan gambaran pneumonia anak dibawah 5 tahun 50 kasus.
\end{abstract}


Coresponden Author:

Email: rsuci9161@gmail.com

Artikel dengan akses terbuka dibawah lisensi

\section{Pendahuluan}

Paru memiliki fungsi yang sangat esensial. Fungsi pertama terkait dengan fungsi ventilasi-perfusi yang mengantarkan oksigen ke seluruh tubuh dan mengeluarkan karbon dioksida yang dihasilkan dari proses metabolisme. Fungsi kedua yaitu perlindungan tubuh terhadap patogen airborne, zat kimia dan partikel lainnya (Broaddus et al., 2016). Fungsi penting ini dibantu oleh struktur makro, histologi dan faktor ultrastruktur lainnya pada pertukaran gas respirasi yang dijumpai pada paru yang sehat.

Fungsi paru yang kedua mencakup pembentukan surfaktan, sekresi dan daur ulang serta mukosiliar clearance, neuroendocrine signaling, sintesa dan sekresi oleh sel epitel dan endotel. Beragam fungsi paru yang kedua ini menekankan pentingnya paru dalam proses homeostasis tubuh. Proses pertukaran gas berhubungan erat dengan ventilasi dan aliran darah. Banyak penyakit paru yang mengganggu fungsi ini, dimana dijumpai kelainan ventilasi, aliran darah dan proses pertukaran gas yang dapat menyebabkan gagal napas dan kematian.

Penyakit paru dapat dibagi menjadi beberapa penyakit infeksi maupun noninfeksi. Adapun penyakit infeksi misalnya Infeksi Saluran Pernafasan Akut (ISPA), Pneumonia, TB Paru dan penyakit paru lainya, sedangkan penyakit non-infeksi dapat dibagi menjadi penyakit paru restriktif dan obstruktif. Beberapa penyakit ini merupakan penyebab kematian dan komorbiditas yang besar bagi usia tertentu, misalnya ISPA dan Pneumonia menjadi penyebab mortalitas

Jurnal Health Sains Vol. 2, No. 2, Februari 2021 terbesar pada anak dan balita (Dugar et al., 2018).

Tuberkulosis merupakan infeksi bakteri menular yang disebabkan Mycobakterium Tuberkulosis yang ditandai dengan pembentukan granuloma pada jaringan yang terinfeksi (Setiati et al., 2016). Chronic obstructive pulmonary disease (COPD)/Penyakit Paru Obstruksi Kronis (PPOK) merupakan gangguan pernapasan yang kompleks, PPOK ditandai dengan hambatan aliran udara dan peningkatan respon inflamasi kronis di saluran udara. Komorbiditas sering terjadi pada PPOK berdampak signifikan pada kualitas hidup, frekuensi eksaserbasi, dan kelangsungan hidup pasien (Vogelmeier et al., 2017).

Global Initiative for Asthma (GINA) mendefinisikan Asma sebagai gangguan inflamasi kronis saluran nafas dengan banyak sel berperan, khususnya sel mast, eosinofil, dan limfosit $\mathrm{T}$. Orang yang rentan tersebut mengalami episode mengi berulang, sesak nafas, rasa dada tertekan, dan batuk, khususnya pada malam atau dini hari (Vogelmeier et al., 2017). Pneumonia adalah peradangan yang mengenai parenkim paru, distal dari bronkiolus terminalis yang mencakup bronkiolus respiratorius, dan alveoli, serta menimbulkan konsolidasi jaringan paru dan gangguan pertukaran gas (Aston, 2017).

Infeksi saluran nafas akut adalah infeksi saluran pernafasan yang berlangsung $<14$ hari. Saluran nafas yang dimaksud adalah organ mulai dari hidung sampai alveoli paru beserta organ adneksanya seperti sinus, ruang telinga tengah, dan pleura (Atmoko et al., 2012). Berdasarkan latar belakang tersebut, 
peneliti tertarik dan ingin melakukan penelitian yang berkaitan dengan "Gambaran Gangguan Respirasi di Kabupaten Aceh Tenggara Tahun 2015-2019". Tujuan Penelitian untuk mengetahui gambaran gangguan respirasi di Kabupaten Aceh Tenggara tahun 2015-2019.

Paru memiliki fungsi yang sangat esensial terkait dengan ventilasi dan perlindungan tubuh terhadap patogen airborne. Tuberkulosis merupakan infeksi bakteri menular yang disebabkan Mycobakterium Tuberkulosis yang ditandai dengan pembentukan granuloma pada jaringan yang terinfeksi. Tuberkulosis biasanya menyerang paru wal aupun dapat menyebar ke hampir seluruh bagian tubuh termasuk usus, ginjal, tulang, nodus limfe. Infeksi awal biasanya terjadi 210 minggu setelah pemajanan (Sari et al., 2018).

Sekitar 10 juta orang di dunia mengalami Tuberkulosis (TB) dan menjadi salah satu dari 10 penyebab utama kematian diseluruh dunia, dan penyebab utama dari satu agen infeksius yaitu Mycobacterium Tuberkulosis, peringkat di atas HIV/AIDS. Penyakit ini dapat menyerang siapa saja di mana saja, tetapi kebanyakan orang yang mengalami TB (sekitar 90\%) adalah orang dewasa, rasio pria: wanita adalah 2:1.

Tingkat kasus di tingkat nasional bervariasi dari $<50$ hingga $>5.000 / 1$ juta populasi/tahun. Hampir 90\% kasus setiap tahun berada di 30 negara dengan TB tinggi. Secara global, diperkirakan 1,7 miliar orang terinfeksi M. Tuberkulosis dan karenanya berisiko terkena penyakit ini. Laporan WHO tahun 2016 memperkirakan sebanyak 8,7 juta orang terjangkit TB Paru dan 1,4 juta orang meninggal. Dilaporkan terdapat 6.216.513 TB Paru kasus baru, dan 2.621.308 merupakan BTA positif. Kasus terbanyak TB Paru antara umur 15-44 tahun, di dapatkan 734.908 kasus (Organization, 2013).
Sepuluh negara penyumbang sekitar $80 \%$ kejadian $\mathrm{TB}$, antara lain: India (25\%), Nigeria (12\%), Indonesia (10\%) dan Filipina (8\%) yang menyumbang lebih dari setengah dari total kejadian TB di dunia. Total kejadian TB di Indonesia adalah 845 (770-923) ribu orang. Kejadian TB HIV-positif di Indonesia adalah sekitar 21 (8.9-38) ribu orang dengan angka kematian TB negatif HIV sekitar 93 (87-99) ribu orang dan TB HIV-positif adalah 5.3 (2.1-9.8) ribu orang. Kejadian TB MDR/RR adalah 24 (17-32) ribu orang (Organization, 2013).

Berdasarkan data dari WHO tahun 2016, angka prevalensi tuberkulosis di Indonesia di perkirakan 395 per 100.000 penduduk dan menyatakan bahwa Indonesia dengan jumlah penduduk 254.831.222 menepati posisi kedua dengan beban Tuberkulosis tertinggi di dunia setelah China. Tuberkulosis di Indonesia juga merupakan penyebab nomor empat kematian setelah kardiovaskular (Organization, 2013). Angka kejadian TB di Indonesia pada tahun 2017 sebanyak 425.089 kasus dengan CNR $162 / 100.000$ penduduk, meningkat bila dibandingkan semua kasus Tuberkulosis yang ditemukan pada tahun 2016 yang sebesar 351.893 kasus dengan CNR 136/100.000 dan tahun 2015 sebesar 330.729 kasus dengan CNR 129/100.000 (Lestari, 2009).

Jumlah kasus tertinggi yang dilaporkan terdapat di tiga provinsi dengan jumlah penduduk yang besar yaitu Jawa Barat 78.698 kasus, disusul oleh Jawa Timur 48.323 kasus dan Jawa Tengah 42.272 kasus. Menurut kelompok umur, kasus Tuberkulosis pada tahun 2017 paling banyak ditemukan pada kelompok umur 25-34 tahun yaitu sebesar 17,32\% diikuti kelompok umur 45-54 tahun sebesar $17,09 \%$ dan pada kelompok umur 35-44 tahun sebesar 16,43\% . Prevalensi kejadian TB di Aceh sebesar 3,9\% atau berada pada rangking 12 di Indonesia. 
TB adalah penyakit infeksi paling mematikan di Aceh.

Berdasarkan data dari Dinas Kesehatan Provinsi Aceh Tahun 2016 ditemukan jumlah kasus baru BTA positif (BTA+) sebanyak 3.410 kasus. Jumlah ini menurun dibandingkan kasus baru BTA+ yang ditemukan tahun 2015 sebanyak 4.023 kasus. Jumlah kasus tertinggi yang dilaporkan terdapat di Kabupaten Pidie sebanyak 351 kasus, diikuti Aceh Besar sebanyak 302 kasus. Menurut jenis kelamin, kasus BTA+ pada laki-laki lebih tinggi daripada perempuan yaitu 1,7 kali dibandingkan kasus BTA+ pada perempuan (Marissa et al., 2020).

Hal ini disebabkan kebiasaan lakilaki yang sering keluar rumah, sehingga kemungkinan banyak terpapar dengan udara dan terhirup droplet yang mengandung kuman TBC. Disparitas paling tinggi antara laki-laki dan perempuan terjadi di Kabupaten Bireuen, Aceh Timur dan Kota Langsa, kasus pada laki-laki hampir tiga kali lipat dari kasus pada perempuan. Angka notifikasi kasus baru BTA+ pada tahun 2016 di Aceh sebesar 67 per $\quad 100.000$ penduduk. Menurun dibandingkan tahun 2015 yang sebesar 80 per 100.000 penduduk (Marissa et al., 2020).

Penurunan ini juga diikuti dengan menurunnya angka notifikasi seluruh kasus TB per 100.000 penduduk. Kasus baru BTA+ pada anak usia 0-14 tahun di Aceh berjumlah 40 kasus atau hanya 0,8\% dari seluruh kasus TB. Penyumbang terbanyak berasal dari Kabupaten Aceh Tenggara sebanyak 7 kasus, diikuti Kabupaten Aceh Tenggara 6 kasus. Terdapat 9 kabupaten/kota yang tidak ada kasus TB pada kelompok umur 0 - 14 tahun. Adapun dua belas kabupaten/kota lainnya menyumbang antara 1 sampai 4 penderita (Marissa et al., 2020).

\section{Metode Penelitian}

Jenis penelitian yang digunakan adalah deskriptif restrospektif. Sumber data yang digunakan adalah data sekunder yang diperoleh dari dinas kesehatan untuk mengetahui gambaran gangguan respirasi di Kabupaten Aceh Tenggara Tahun 2015-2019.

Populasi dalam penelitian ini adalah seluruh pasien yang mengalami gangguan respirasi di Kabupaten Aceh Tenggara Tahun 2015-2019.

Sampel dalam penelitian ini adalah seluruh pasien yang mengalami gangguan respirasi yang memenuhi kriteria inklusi dan eksklusi.

1. Kriteria inklusi

a. Data pasien yang terdiagnosa gangguan respirasi.

b. Data lengkap pasien dengan gangguan respirasi di Dinas Kesehatan Kabupaten Aceh Tenggara 2015-2019.

\section{Kriteria eksklusi}

Pasien yang tidak memiliki data lengkap di Dinas Kesehatan Kabupaten Aceh Tenggara.

Instrumen yang akan digunakan dalam penelitian ini adalah data sekunder yang diperoleh dari dinas kesehatan Kabupaten Aceh Tenggara mengenai gangguan respirasi. Alat ukur yang digunakan adalah SP2TP (sistem pencatatan dan pelaporan data tingkat puskesmas) dengan cara observasi data. Penelitian ini dilakukan di Dinas Kesehatan Kabupaten Aceh Tenggara melalui data pelaporan gangguan respirasi pada tahun 2015-2019. Penelitian ini dilakukan pada bulan Maret sampai Juni 2020.

\section{Hasil Penelitian}

Pengumpulan data dilakukan dari bulan Maret - Juni tahun 2020 di Dinas Kesehatan Kabupaten Aceh Tenggara aspek yang diteliti gambaran gangguan respirasi di Kabupaten Aceh Tenggara. Hasil penelitian yang diperoleh adalah sebagai berikut : 
1. Kejadian Tuberkulosis

Distribusi kategori

tuberkulosis yang didapatkan melalui pencatatan di Dinas Kesehatan Kabupaten Aceh Tenggara mendapatkan hasil sebagai berikut :

Tabel 4.1

Distribusi Pasien Tuberkulosis Pada 5 Tahun Terakhir Berdasarkan Jenis Kelamin

\begin{tabular}{ccccccc}
\hline Tahun & $\begin{array}{c}\text { Laki- } \\
\text { Laki }\end{array}$ & $\%$ & Perempuan & $\%$ & Total & $\%$ \\
\hline 2015 & 65 & 9.6 & 33 & 4.9 & 98 & 14.5 \\
\hline 2016 & 87 & 12.9 & 43 & 6.4 & 130 & 19.3 \\
\hline 2017 & 131 & 19.4 & 72 & 10.7 & 203 & 30.1 \\
\hline 2018 & 65 & 9.6 & 25 & 3.7 & 90 & 13.3 \\
\hline 2019 & 108 & 16 & 46 & 6.8 & 154 & 22.8 \\
\hline Total & 456 & 67.5 & 219 & 32.5 & 675 & 100 \\
\hline & \multicolumn{7}{c}{ (SP2TP, 2020$)$} \\
\end{tabular}

Pada tabel 4.1 distribusi karakteristik pasien tuberkulosis pada lima tahun terakhir berdasarkan jenis kelamin, dari 675 penderita TB terdapat $30.1 \%$ (203) penderita pada tahun 2017 yang terbanyak dari jenis kelamin lakilaki sebesar $19.4 \%$ (131) dan perempuan $10.7 \%$ (72) penderita. Hal ini memberikan gambaran bahwa kejadian TB pada tahun 2017 memiliki persentase yang besar dibandingkan dengan periode tahun lainya.

\section{Kejadian Asma}

Distribusi kategori asma yang didapatkan melalui pencatatan di Dinas Kesehatan Kabupaten Aceh Tenggara mendapatkan hasil sebagai berikut :

Tabel 4.2

Distribusi Pasien Asma Berdasarkan

Tahun

\begin{tabular}{ccc}
\hline TAHUN & N & $\%$ \\
\hline 2015 & 2824 & 16.5 \\
\hline 2016 & 3631 & 21.2 \\
\hline 2017 & 3227 & 18.8 \\
\hline 2018 & 3429 & 20 \\
\hline 2019 & 4034 & 23.5 \\
\hline JUMLAH & 17145 & 100
\end{tabular}

(SP2TP, 2020)

Pada tabel 4.2 distribusi karakteristik pasien asma berdasarkan tahun, dari 17145 pasien asma, terdapat 23.5\% (4034) penderita pada tahun 2019. Hal ini memberikan gambaran bahwa kejadian asma pada tahun 2019 memiliki persentase yang besar dibandingkan dengan periode tahun lainya. Jumlah penduduk Kabupaten Aceh Tenggara 208,481 jiwa berdasarkan pencatatan badan statistik Kabupaten Aceh Tenggara Tahun Tahun 2017.

\section{Kejadian PPOK}

Distribusi kategori PPOK yang didapatkan melalui pencatatan di Dinas Kesehatan Kabupaten Aceh Tenggara mendapatkan hasil sebagai berikut :

Tabel 4.3

Distribusi Pasien PPOK Berdasarkan Tahun

\begin{tabular}{ccc}
\multicolumn{3}{c}{ Tahun } \\
\hline TAHUN & $\mathbf{N}$ & $\%$ \\
\hline 2015 & $\mathbf{4 0 3}$ & $\mathbf{1 6 . 5}$ \\
\hline 2016 & $\mathbf{4 6 1}$ & $\mathbf{1 8 . 8}$ \\
\hline 2017 & $\mathbf{5 1 8}$ & $\mathbf{2 1 . 2}$ \\
\hline $\mathbf{2 0 1 8}$ & $\mathbf{4 9 0}$ & $\mathbf{2 0}$ \\
\hline $\mathbf{2 0 1 9}$ & $\mathbf{5 7 6}$ & $\mathbf{2 3 . 5}$ \\
\hline JUMLAH & $\mathbf{2 4 4 8}$ & $\mathbf{1 0 0}$ \\
\hline & (SP2TP, 2020)
\end{tabular}

Pada tabel 4.3 distribusi karakteristik pasien PPOK berdasarkan tahun, dari 2448 penderita PPOK, terdapat 23.5\% (576) penderita pada tahun 2019. Hal ini memberikan gambaran bahwa kejadian PPOK pada tahun 2019 memiliki persentase yang besar dibandingkan dengan periode tahun lainya.

\section{Kejadian ISPA}

Distribusi kategori ISPA yang didapatkan melalui pencatatan di Dinas Kesehatan Kabupaten Aceh Tenggara mendapatkan hasil sebagai berikut : 
Tabel 4.4

Distribusi Pasien ISPA Pada Lima

Tahun Terakhir Berdasarkan Umur

\begin{tabular}{ccccccc}
\hline Tahun & $<5$ Tahun & $\%$ & $>5$ Tahun & $\%$ & Total & $\%$ \\
\hline 2015 & 6400 & 6.7 & 13358 & 14 & 19758 & 20.7 \\
\hline 2016 & 6571 & 6.9 & 15400 & 16.1 & 21971 & 23 \\
\hline 2017 & 3234 & 3.4 & 10407 & 10.9 & 13641 & 14.3 \\
\hline 2018 & 4849 & 5.1 & 14283 & 15 & 19132 & 20.1 \\
\hline 2019 & 6252 & 6.6 & 14589 & 15.3 & 20841 & 21.9 \\
\hline Total & 27306 & 28.7 & 68037 & 71.3 & 95343 & 100 \\
\hline \multicolumn{7}{c}{ (SP2TP, 2020) } \\
\end{tabular}

Pada tabel 4.4 distribusi karakteristik pasien ISPA pada lima tahun terakhir berdasarkan umur, dari 95343 penderita ISPA, terdapat $23 \%$ (21971) penderita pada tahun 2016 yang terbanyak dari umur $>5$ tahun sebesar $16.1 \%(15400)$ dan umur $<5$ tahun $6.9 \%$ (6571) penderita. Hal ini memberikan gambaran bahwa kejadian ISPA pada tahun 2016 memiliki persentase yang besar dibandingkan dengan periode tahun lainya. Jumlah penduduk Kabupaten Aceh Tenggara 208,481 jiwa berdasarkan pencatatan badan statistik Kabupaten Aceh Tenggara 2017.

\section{Kejadian Pneumonia}

Distribusi kategori pneumonia dengan umur dibawah 5 tahun yang didapatkan melalui pencatatan di Dinas Kesehatan Kabupaten Aceh Tenggara mendapatkan hasil sebagai berikut :

Tabel 4.5

Distribusi Pasien Pneumonia Berdasarkan Tahun

\begin{tabular}{ccc}
\hline TAHUN & N & $\%$ \\
\hline 2015 & 0 & 0 \\
\hline 2016 & 0 & 0 \\
\hline 2017 & 0 & 0 \\
\hline 2018 & 17 & 34 \\
\hline 2019 & 33 & 66 \\
\hline JUMLAH & 50 & 100 \\
\hline
\end{tabular}

(SP2TP, 2020)
Pada tabel 4.5 distribusi karakteristik pasien pneumonia berdasarkan tahun, dari 50 penderita pneumonia, terdapat $66 \%$ (33) penderita pada tahun 2019. Pada tahun 2015-2017 terjadi kehilangan data dari SP2TP sehingga mengakibatkan angka kejadian dari tahun 2015-2017 menjadi kosong.

\section{Pembahasan}

\section{Kejadian Tuberkulosis}

Berdasarkan tabel 4.1 menunjukan bahwa kategori Tuberkulosis didapatkan kejadian sebanyak 675 kasus dari tahun 2015-2019 dengan paling banyak terjadi pada laki-laki 456 (67.5\%) dibandingkan dengan perempuan 219 (32.5\%). Angka kejadian pada tahun 2015 sebanyak 98 (14.5\%), pada tahun 2016 sebanyak 130 (19.3\%), pada tahun 2017 sebanyak 203 (30.1\%), pada tahun 2018 sebanyak 90 (13.3\%), dan pada tahun 2019 sebanyak $154(22.8 \%)$ yang berarti angka tertinggi pada tahun 2017 (30.1\%).

Hal ini sesuai dengan penelitian Jendra dengan judul penelitian Hubungan Faktor Risiko Umur, Jenis Kelamin dan Kepadatan Hunian Dengan Kejadian Penyakit TB di Desa Wori Kecamatan Wori, didapatkan hasil yang memiliki jenis kelamin laki-laki (59.8\%) lebih banyak terkena Tuberkulosis dibandingkan dengan perempuan $(40.2 \%)$ dengan nilai $\mathrm{P}=0.000$. Hal ini sesuai dengan kepustakaan bahwa laki-laki lebih berisiko besar untuk terkena penyakit tuberkulosis dibandingkan perempuan, dikarenakan faktor risiko merokok dan minum alkohol dapat menurunkan imunitas tubuh sehingga lebih mudah untuk terkena penyakit tuberculosis (Dotulong et al., 2015).

Penelitian Jendra dengan judul Hubungan Faktor Risiko Umur, Jenis Kelamin dan Kepadatan Hunian Dengan 
Kejadian Penyakit TB di Desa Wori Kecamatan Wori menunjukan orang yang banyak terkena tuberkulosis adalah kelompok umur 15-54 tahun sebanyak (67\%) dibandingkan pada kelompok umur $>55$ tahun sebanyak (33\%) dengan nilai $\mathrm{P}=0.012$. Orang yang dengan lingkungan kerja yang padat serta berhubungan dengan orang banyak juga dapat meningkatkan terjadinya tuberculosis (Dotulong et al., 2015).

\section{Kejadian Asma}

Berdasarkan tabel 4.2 di atas menunjukan bahwa kategori asma didapatkan kejadian sebanyak 17145 kasus dari tahun 2015-2019 dengan paling tinggi terjadi pada tahun 2019 $(23.5 \%)$. \%). Angka kejadian pada tahun 2015 sebanyak 2824 (16.5\%), pada tahun 2016 sebanyak 3631 (21.2\%), pada tahun 2017 sebanyak 3227 (18.8\%), pada tahun 2018 sebanyak 3429 (20\%), dan pada tahun 2019 sebanyak 4034 (23.5\%) yang berarti angka tertinggi pada tahun 2019 $(23.5 \%)$.

Hal ini sesuai dengan penelitian Adefri dengan judul penelitian Hubungan Faktor Risiko Terhadap Kejadian Asma Pada Anak di RSUP Dr.M.Djamil Padang didapatkan hasil yang memiliki jenis kelamin perempuan $(48.7 \%)$ lebih banyak terkena asma dibandingkan dengan lakilaki (51.3\%). Hubungan antara jenis kelamin dengan kejadian asma sangat kompleks karena bersifat multifactorial salah satunya tingkat kepatuhan dan keberadaan hewan (Wahyudi et al., 2016).

Penelitian Adefri dengan judul penelitian Hubungan Faktor Risiko Terhadap Kejadian Asma Pada Anak di RSUP Dr.M.Djamil Padang didapatkan hasil yang memiliki umur dibawah 5 tahun sebanyak (51.3\%) dan yang berumur lebih dari 5 tahun sebanyak (48.7\%). Tingginya kejadian serangan asma pada balita disebabkan oleh belum matangnya sistem imun keseimbangan Th1/Th2 pada balita sehingga menyebabkan lebih mudah terserang asma (Wahyudi et al., 2016).

3. Kejadian PPOK

Berdasarkan tabel di atas menunjukan bahwa kategori PPOK didapatkan kejadian sebanyak 2448 kasus dari tahun 2015-2019 dengan paling tinggi terjadi pada tahun 2019 (23.5\%). Angka kejadian pada tahun 2015 sebanyak 403 (16.5\%), pada tahun 2016 sebanyak 461 (18.8\%), pada tahun 2017 sebanyak 518 (21.2\%), pada tahun 2018 sebanyak 490 (20\%), dan pada tahun 2019 sebanyak 576 (23.5\%) yang berarti angka tertinggi pada tahun 2019 (23.5\%).

Penelitian Fadhil dalam judul penelitian gambaran Derajat Merokok Pada Penderita PPOK di Bagian Paru RSUP Dr.M.Djamil pada kelompok umur 60 tahun keatas (95\%) dibandingkan umur yang lebih muda (5\%). Hal ini berhubungan dengan penurunan fungsi paru yang lebih cepat menurun pada orang yang masih merokok setelah berumur lebih dari 45 tahun. Faal paru yang menurun secara terus menerus akan meningkatkan tingkat keparahan PPOK pada umur lebih dari 45 tahun (el Naser et al., 2016).

Penelitian Ofisa Fajrin dalam judul Gambaran Status Gizi dan Fungsi Paru Pada Pasien Penyakit Paru Obstruktif Kronik Stabil di Poli Paru RSUD Arifin Achmad lebih banyak terjadi pada lakilaki (88.4\%) dibandingkan dengan perempuan $(22.6 \%)$, hal ini kemungkinan karena pengaruh pergaulan, lebih sedikitnya wanita yang merokok karena adanya pengaruh norma masyarakat yaitu perokok wanita dinilai memiliki perilaku yang negative (el Naser et al., 2016).

4. Kejadian ISPA 
Berdasarkan tabel di atas menunjukan bahwa kategori ISPA didapatkan kejadian sebanyak 95343 kasus dari tahun 2015-2019 dengan paling tinggi terjadi pada tahun 2015 (26.1\%). Angka kejadian pada tahun 2015 sebanyak 26716 (26.1\%), pada tahun 2016 sebanyak 21971 (21.5\%), pada tahun 2017 sebanyak 13641 (13.3\%), pada tahun 2018 sebanyak 19132 (18.7\%), dan pada tahun 2019 sebanyak 20841 (20.4\%) yang berarti angka tertinggi pada tahun 2015 (26.1\%).

Penelitian Firda Fibrila dengan judul Hubungan Usia Anak, Jenis Kelamin, dan Berat Badan Lahir Anak Dengan Kejadian ISPA menunjukan hasil anak umur balita (58.3\%) dibandingkan dengan anak umur diatas 5 tahun. ISPA merupakan infeksi saluran yang berawal dari saluran pernafasan hidung, tenggorokan, larynx, trachea, broncho, dan alveoli, pada anak umur 10 tahun pertama kehidupan manusia sistem pernafasan masih terus berkembang untuk mencapai fungsi yang sempurna terutama dalam pembentukan alveoli (Fibrila, 2016).

5. Kejadian Pneumonia

Berdasarkan tabel 4.5 menunjukan bahwa kategori pneumonia didapatkan kejadian sebanyak 50 kasus dari tahun 2015-2019 di Kabupaten Aceh Tenggara dengan paling tinggi terjadi pada tahun 2019 (23.5\%). Prevalensi pneumonia pada tahun 2015-2017 adalah nilil (0\%), pada tahun 2018 (34\%) dan pada tahun 2019 didapatkan (66\%).

Penelitian Linda dengan judul Hubungan Pemberian ASI Eksklusif dan Bayi Berat Lahir Rendah (BBLR) dengan kejadian pneumonia pada balita umur 1259 bulan di wilayah kerja Puskesmas Kamonji menunjukan kejadian pneumonia sebesar (50\%). Faktor terjadinya pneumonia dapat berupa status gizi pada anak dibawah 59 bulan, status gizi yang kurang dapat menyebabkan sistem kekebalan tubuh balita mudah terserang penyakit (Linda, 2018).

\section{Kesimpulan}

Berdasarkan penelitian yang telah dilakukan di Dinas Kesehatan Kabupaten Aceh Tenggara pada Maret-Juni 2020, diperoleh, pertama gambaran tuberkulosis di Kabupaten Aceh Tenggara dari tahun 20152019 sebanyak 675 kasus dan jenis kelamin paling tinggi adalah laki-laki (67.5\%). Kedua Gambaran asma di Kabupaten Aceh Tenggara dari tahun 2015-2019 sebanyak 17145 kasus.

Ketiga gambaran PPOK di Kabupaten Aceh Tenggara dari tahun 2015-2019 sebanyak 2448 kasus.

Keempat gambaran ISPA di Kabupaten Aceh Tenggara dari tahun 2015-2019 sebanyak 95343 dan yang berumur $<5$ tahun $(28.7 \%)$ serta $>5$ tahun $(71.3 \%)$.

Kelima gambaran pneumonia pada umur $<5$ tahun di Kabupaten Aceh Tenggara dari tahun 2015-2019 sebanyak 50 kasus. 


\section{BIBILIOGRAFI}

Aston, S. J. (2017). Pneumonia In The Developing World: C Haracteristic Features And Approach To Management. Respirology, 22(7), 12761287.

Atmoko, W., Suyatno Hadi, S., Festy, P., \& Km, S. (2012). Asuhan Keperawatan Pada Tn "A" Penderita Tuberkulosis Paru Dengan Hemaptoe Di Ruang Leci Rumah Sakit Paru Surabaya. Universitas Muhammadiyah Surabaya.

Broaddus, V. C., Mason, R. J., Ernst, J. D., King Jr, T. E., Lazarus, S. C., Murray, J. F., Nadel, J. A., Slutsky, A. S., \& Gotway, M. B. (2016). Murray \& Nadel's Textbook Of Respiratory Medicine. Elsevier.

Dotulong, J., Sapulete, M. R., \& Kandou, G. D. (2015). Hubungan Faktor Risiko Umur, Jenis Kelamin Dan Kepadatan Hunian Dengan Kejadian Penyakit Tb Paru Di Desa Wori Kecamatan Wori. Jurnal Kedokteran Komunitas Dan Tropik, 3(2).

Dugar, S. P., Latifi, M., \& MirelesCabodevila, E. (2018). Respiratory System Physiology. In Basic Sciences In Anesthesia (Pp. 329-354). Springer.

El Naser, F., Medison, I., \& Erly, E. (2016). Gambaran Derajat Merokok Pada Penderita Ppok Di Bagian Paru Rsup Dr. M. Djamil. Jurnal Kesehatan Andalas, 5(2).

Fibrila, F. (2016). Hubungan Usia Anak, Jenis Kelamin Dan Berat Badan Lahir Anak Dengan Kejadian Ispa. Jurnal Kesehatan Metro Sai Wawai, 8(2), 813.

Lestari, S. (2009). Sistem Informasi Klinik Gigi Untuk Evaluasi Pelayanan Kesehatan Gigi Pada Politeknik Kesehatan Depkes Semarang. Program Pasca Sarjana Universitas Diponegoro.
Linda, L. (2018). Hubungan Pemberian Asi Eksklusif Dan Bayi Berat Lahir Rendah (Bblr) Dengan Kejadian Pneumonia Pada Balita Umur 12-59 Bulan Di Wilayah Kerja Puskesmas Kamonji. Husada Mahakam: Jurnal Kesehatan, 4(5), 277-287.

Marissa, N., Wilya, V., Febriansyah, E., \& Ramadhan, N. (2020). Tes Cepat Molekuler Sebagai Alat Diagnosis Tuberkulosis Yang Resisten Rifampisin Di Provinsi Aceh. Jurnal Biotek Medisiana Indonesia, 9(2), 147-159.

Organization, W. H. (2013). Global Tuberculosis Report 2013. World Health Organization.

Sari, I. D., Herman, M. J., Susyanty, A. L., \& Su'udi, A. (2018). Analisis Biaya Tuberkulosis Paru Kategori Satu Pasien Dewasa Di Rumah Sakit Di Dki Jakarta. Jurnal Kefarmasian Indonesia, 8(1), 44-54.

Setiati, S., Alwi, I., Sudoyo, A. W., Simadibrata, K., Setiyohadi, B., \& Syam, A. F. (2016). Buku Ajar Ilmu Penyakit Dalam. Interna Publishing.

Vogelmeier, C. F., Criner, G. J., Martinez, F. J., Anzueto, A., Barnes, P. J., Bourbeau, J., Celli, B. R., Chen, R., Decramer, M., \& Fabbri, L. M. (2017). Global Strategy For The Diagnosis, Management, And Prevention Of Chronic Obstructive Lung Disease 2017 Report. Gold Executive Summary. American Journal Of Respiratory And Critical Care Medicine, 195(5), 557-582.

Wahyudi, A., Yani, F. F., \& Erkadius, E. (2016). Hubungan Faktor Risiko Terhadap Kejadian Asma Pada Anak Di Rsup Dr. M. Djamil Padang. Jurnal Kesehatan Andalas, 5(2). 
Gambaran Gangguan Respirasi Di Kabupaten Aceh Tenggara Tahun 2015-2019 